\title{
Analisis Fenomena El Nino dan Dampaknya Terhadap Neraca Air Lahan di Pulau Ambon
}

\author{
Analyses of El Nino Phenomenon and Its Impact on Land Water Balance in Ambon Island
}

\section{Semuel Laimeheriwa ${ }^{1, *}$, Mitha Pangaribuan², Martha Amba ${ }^{1}$}

\author{
${ }^{1}$ Jurusan Budidaya Pertanian, Faultas Pertanian, Universitas Pattimura, Jl. Ir. M. Putuhena, Kampus Poka Ambon 97233 \\ ${ }^{2}$ Program Studi Agroekoteknologi, Jurusan Budidaya Pertanian, Faultas Pertanian, Universitas Pattimura, Jl. Ir. M. \\ Putuhena, Kampus Poka Ambon 97233 \\ *E-mail Penulis Korespondensi: laimeheriwasamuel@yahoo.co.id
}

\begin{abstract}
El Nino is one of the global phenomena that has affected the climate system of Indonesia, including Ambon Island of Maluku. One of the direct impacts of the El Nino phenomenon is the decrease of water availability on agricultural land. This study aimed: i) to analyze the period of El-Nino extreme rainfall events in Ambon Island as well as the intensity and its frequency; and ii) to analyze the impact of El Nino events on the water balance of agricultural lands on Ambon Island. Sixty years of climatic data period 1959-2018 from Pattimura Meteorological Station and Karang Panjang Geophysics Station were used to analyze extreme rainfall conditions of El Nino, and to calculate the water balance of land using the methods of Thornthwaite and Mather (1957). The results showed that 16 times El Nino events occurred in Ambon between 1959 and 2018, with the frequency of 1-7 times per year or four times per year. The most extreme El Nino events that occurred in Ambon were in 1977, 1987 and 1997. The results of land water balance calculation during the El-Nino events showed seven months water deficit (September to March) which is 62,6\% higher than the normal conditions; meanwhile, the optimum soil moisture occurred four months (June to September) or seven months shorter than the normal conditions which were 11 months (March to January).
\end{abstract}

Keywords: Ambon Island, El Nino, land-water balance

\section{ABSTRAK}

El Nino merupakan salah satu fenomena global yang berdampak terhadap sistem iklim di wilayah Indonesia; termasuk wilayah Pulau Ambon Provinsi Maluku. Salah satu dampak langsung fenomena El Nino terhadap sistem pertanian adalah berkurangnya ketersediaan air pada lahan pertanian. Penelitian bertujuan untuk: a) menganalisis tahuntahun kejadian curah hujan ekstrim El Nino serta intensitas dan frekuensinya di Pulau Ambon; dan b) menganalisis dampak kejadian El Nino terhadap neraca air lahan pertanian di Pulau Ambon. Penelitian ini menggunakan data iklim selama 60 tahun pengamatan periode 1959-2018 dari Stasiun Meteorologi Pattimura Ambon dan Stasiun Geofisika Karang Panjang Ambon. Analisis data iklim dilakukan dengan tahapan sebagai berikut: a) analisis curah hujan pada kondisi ekstrim El Nino; dan b) perhitungan neraca air lahan menggunakan metode Thornthwaite dan Mather (1957). Hasil penelitian menunjukkan bahwa selama periode 1959-2018 kejadian El Nino berlangsung di Pulau Ambon sebanyak 16 kali dengan frekuensi 1-7 tahun sekali atau rata-rata 4 tahun sekali. Tahun-tahun kejadian El Nino di wilayah Pulau Ambon yang paling ekstrim terjadi pada tahun 1977, 1987 dan 1997. Berdasarkan perhitungan neraca air lahan, ketika El-Nino berlangsung defisit air terjadi selama 7 bulan (September sampai dengan Maret); nilainya bertambah sebesar $626 \%$ dari kondisi normal, dan kadar air tanah pada kondisi optimum hanya 4 bulan (Juni sampai dengan September) atau lebih pendek 7 bulan dibandingkan kondisi normalnya, yaitu 11 bulan (Maret sampai dengan Januari).

Kata kunci: El Nino, neraca air lahan, Pulau Ambon

\section{PENDAHULUAN}

Informasi iklim/cuaca suatu wilayah sangat dibutuhkan dalam mengidentifikasi potensi dan daya dukung wilayah untuk penetapan strategi dan arah kebijakan pembangunan berbagai sektor. Pada sektor pertanian, setiap daerah di Indonesia memiliki keragaman dan keadaan yang khas, termasuk keadaan iklim. Hal ini menyebabkan interaksi antara tanaman dengan kondisi iklim/cuaca berbeda antara suatu tempat dengan tempat lainnya. Dalam kaitan ini, Informasi keadaan iklim suatu tempat memegang peranan penting bagi bentuk dan pengembangan pertanian tempat tersebut; karena dengan memanfaatkan pengetahuan tentang hubungan antara tanaman dan iklim dapatlah dibuat prakiraan waktu tanam, waktu panen, kejadian 
kekeringan (defisit air), banjir (surplus air), serangan hama dan penyakit, penentuan jenis tanaman yang sesuai, dan sebagainya.

Dari berbagai hasil penelitian menunjukkan bahwa akhir-akhir ini kejadian iklim ekstrim semakin sering terjadi baik dari sisi intensitas maupun frekuensinya, sementara itu ada kecenderungan sudah terjadi perubahan pola iklim dunia akibat pemanasan global dan cenderung terus berlangsung (Kaimuddin, 2000; Boer et al., 2003, Laimeheriwa, 2014b). Menurut IPCC (2001), dampak negatif yang ditimbulkan akibat kejadian iklim ekstrim dan perubahan iklim tersebut diantaranya menurunnya produksi potensial pertanian akibat naiknya suhu, berkurangnya ketersediaan air wilayah akibat kekeringan, meluasnya wilayah beresiko banjir dan longsor, kenaikan muka air laut, meningkatnya jumlah manusia yang terekspose terhadap penyakit menular. Laimeheriwa (2015) menyatakankan bahwa dampak positif akibat perubahan iklim tersebut seperti meningkatnya jumlah curah hujan selama musim kemarau akan meningkatkan intensitas tanam atau luas panen beberapa komoditi tanaman pangan.

Kondisi cuaca ekstrim seperti fenomena El-Nino (berdasarkan nilai ONI; Oceanic Nino Index pada daerah Nino 3.4 di Samudera Pasifik) akibat dampak pemanasasan global yang terus terjadi hingga saat ini telah berdampak hingga skala lokal; diantaranya terhadap ketersediaan air di suatu wilayah; termasuk pada lahan pertanian. Di wilayah Indonesia secara umum, fenomena El Nino (kekeringan) telah berdampak terhadap penurunan produksi pertanian khususnya tanaman pangan akibat berkurangnya ketersediaan air tanah. Utami et al. (2011) menyatakan bahwa anomali iklim El Nino dapat menurunkan produksi tanaman pangan tapi tidak berpengaruh secara ekonomi terhadap penawaran padi dan jagung di Pulau Jawa. Menurut Nabilah et al. (2017), pergeseran musim yang terjadi di wilayah Indonesia karena fenomena El Nino berpengaruh besar terhadap produksi pangan dan komoditas pertanian yang lain.

Fakta menunjukkan bahwa kejadian kekeringan pada suatu wilayah di Indonesia tidak selalu bersamaan dengan kejadian El Nino, dan kejadian El Nino tidak selalu menyebabkan kekeringan atau curah hujan dibawah normal pada wilayah tertentu. Disamping itu, intensitas serta frekuensi kejadian El Nino relatif berbeda antar daerah dengan pola hujan terntentu (moonson, lokal, atau ekuatorial). Kondisi ini bisa terjadi akibat kondisi maritim nusantara dengan posisi geografis dan topofisiografis pulau yang beragam serta pengaruh sistem monsoon yang berbeda antar lokasi. Menurut Laimeheriwa (2014), kondisi kekeringan (misalnya akibat El Nino) berbeda antar lokasi/wilayah maupun antar musim penghujan maupun musim kemarau. Irwandi et al. (2017) menyatakan bahwa perbedaan posisi geografis dan topofisiografi wilayah menyebabkan adanya variabilitas curah hujan antar wilayah ketika El Nino terjadi.

Hasil penelitian Osok et al. (2017) dan Nangimah et al. (2018) pada wilayah dengan pola hujan moonson di
Maluku menunjukkan bahwa fenomena El Nino berdampak pada penurunan kadar air tanah (defisit air) tahunan dari kondisi normalnya sebesar $172 \%$ di Daerah Waeapo Pulau Buru hingga 244\% di Pulau Wamar Kabupaten Kepulauan Aru. Disamping itu, realitas di lapangan menunjukkan bahwa dalam beberapa tahun belakangan ini kekeringan akibat fenomena El Nino telah berdampak pada pendeknya musim tanam, gagal tanam, gagal panen, serta kekeringan yang berkepanjangan hingga kebakaran lahan pada sebagian besar lokasi di Maluku dan wilayah Indonesia pada umumnya.

Wilayah yang paling rentan terhadap perubahan iklim adalah pulau-pulau kecil. Pulau Ambon merupakan salah satu pulau kecil di wilayah Provinsi Maluku yang memiliki pola hujan lokal tentunya sangat rentan terhadap perubahan iklim seperti kejadian iklim ekstrim El Nino (Sitaniapessy, 2002; Laimeheriwa, 2014b). Fakta di lapangan menunjukkan bahwa ketika fenomena El Nino tahun 2015 telah berdampak pada berkurangnya ketersediaan air wilayah (termasuk lahan pertanian) dan berdampak lanjut terhadap pendeknya musim tanam, gagal tanam hingga gagal panen beberapa komoditi pertanian di Pulau Ambon. Dampak lainnya akibat fenomena ini adalah periode kekeringan yang lebih panjang dari biasanya hingga terjadinya kebakaran lahan (pertanian, hutan, alang-alang, dan semak belukar) pada beberapa titik/lokasi di wilayah ini (Osok et al., 2019). Implikasinya, berapa intensitas dan frekuensi fenomena El Nino di suatu wilayah dengan pola hujan tertentu dan sejauh mana dampaknya terhadap ketersediaan air tanah di suatu wilayah perlu dikaji sehingga diperoleh suatu informasi yang aplikatif dalam pengembangan wilayah; khususnya pada sektor pertanian sambil melakukan upaya antisipasi dan adaptasinya.

Penelitian ini bertujuan untuk: 1) menganalisis tahun-tahun kejadian curah hujan ekstrim El Nino serta intensitas dan frekuensinya di Pulau Ambon, dan 2) menganalisis dampak kejadian curah hujan ekstrim El Nino terhadap neraca air lahan pertanian di Pulau Ambon.

\section{METODOLOGI PENELITIAN}

\section{Lokasi Penelitian}

Penelitian ini dilaksanakan di Pulau Ambon. Adanya perbedaan jumlah curah hujan antara bagian selatan dengan bagian utara Pulau Ambon akibat bentangan topofisiografi pulau dan pengaruh sistem moonson, maka lokasi penelitian berada di bagian selatan Pulau Ambon tepatnya di wilayah Kota Ambon dan sebagiannya termasuk wilayah Kabupaten Maluku Tengah, yaitu Kecamatan Leihitu Barat di ujung barat Pulau Ambon dan Kecamatan Salahutu di ujung timur Pulau Ambon.

\section{Bahan dan Alat}

Bahan yang digunakan dalam penelitian ini adalah data iklim berupa curah hujan dan suhu udara 
serta data penunjang lainnya. Data yang tidak tersedia akan dibangkitkan melalui pendekatan statistikmatematik berdasarkan indikator fisik wilayah. Alat yang digunakan adalah: MS Word 2010, MS Excel 2010, komputer, dan alat tulis menulis.

\section{Pengumpulan Data}

Pengumpulan data pada penelitian ini dilakukan dengan tujuan utama menyiapkan data iklim dan data lainnya yang akan digunakan dalam analisis kejadian El Nino dan perhitungan neraca air lahan. Data iklim terdiri dari: 1) curah hujan 60 tahun terakhir (periode 19592018) dan suhu udara 15 tahun terakhir (periode 20042018) yang tercatat di Stasiun Meteorologi Pattimura Ambon dan Stasiun Geofisika Karang Panjang Ambon, 2) data lainnya berupa jenis tanah, letak lintang dan bujur, data ENSO History Zona NINO 3.4 (NOAA, 2019), dan data penunjang lainnya.

\section{Analisis Data}

\section{Analisa curah hujan pada kondisi ekstrim EI Nino}

Analisis menggunakan data time series curah hujan 60 tahun terakhir (periode 1959-2018). Penentuan kondisi curah hujan ekstrim El Nino setiap tahunnya berupa nilai curah hujan dibawah normal sesuai standar Badan Meteorologi Klimatologi dan Geofisika (BMKG), yaitu curah hujan sebesar $<0,85$ dari nilai curah hujan rata-rata (normal). Penentuan curah hujan rata-rata (normal) menggunakan teknik rata-rata aljabar sebagai berikut:

$$
P b=\sum_{i=1}^{n} P i / n
$$

dimana: $\mathrm{Pb}=$ Curah hujan rataan bulanan $(\mathrm{mm}) ; \mathrm{Pi}=$ Curah hujan bulan tertentu pada tahun ke- $i(\mathrm{~mm}) ; \mathrm{n}=$ Jumlah tahun pengamatan

Kejadian curah hujan di bawah normal setiap tahunnya kemudian disesuiakan dengan tahun-tahun kejadian El-Nino di Indonesia dari data ENSO History Zona NINO 3.4 untuk menentukan tahun-tahun kejadian El-Nino, intensitas, dan frekuensinya di wilayah Pulau Ambon.

\section{Analisis neraca air lahan}

Analisis neraca air lahan bertujuan untuk mengetahui fluktuasi kadar air tanah secara periodik (bulanan) menggunakan metode Thornthwaite dan Mather (1957). Data curah hujan yang digunakan disamping nilai rata-rata curah hujan terekstrim selama tiga tahun kejadian El-Nino dalam kurun waktu 60 tahun periode 1959-2018 juga nilai rata-ratanya (kondisi normal) sebagai pembanding. Tahapan perhitungan neraca air lahan mengikuti langkah-langkah sebagai berikut:

a. Menyusun tabel isian neraca air bulanan;

b. Mengisi kolom curah hujan, $\mathrm{CH}$;

c. Mengisi kolom suhu udara, T;

d. Mengisi kolom evapotranspirasi potensial, ETp; e. Menghitung nilai $\mathrm{CH}-\mathrm{ETp}$

f. Hasil negatif pada langkah (e) diakumulasikan bulan demi bulan sebagai APWL (akumulasi air yang hilang secara potensial) dan diisi pada kolom yang bersangkutan

g. Menentukan nilai kapasitas lapang (KL), titik layu permanen (TLP), water holding capacity (WHC) atau air tersedia dan kedalaman tinjau $1 \mathrm{~m}$; yaitu kedalaman perakaran maksimum untuk tanaman umur pendek atau semusim. Berdasarkan sebaran jenis tanah di Pulau Ambon yang dominannya bertekstur lempung berpasir hingga lempung berliat maka ditentukan nilai KL, TLP, dan WHC untuk lokasi penelitian masing-masing sebesar 310, 140, dan $170 \mathrm{~mm} / \mathrm{m}$ kedalaman tanah.

h. Mengisi kolom kandungan air tanah (KAT), dimulai dari awal terjadinya APWL hingga APWL terakhir. Lanjutkan pengisian KAT untuk bulan-bulan berikutnya yang mempunyai nilai $\mathrm{CH}-\mathrm{ETp}$ positip, dimana nilai KAT maksimum = nilai KL.

i. Untuk menentukan nilai KAT (awal APWL dan seterusnya) dihitung dengan persamaan :

$\mathrm{KSA}=\mathrm{WHC} \times \mathrm{k}|\mathrm{APWL}|$

$\mathrm{WHC}=\mathrm{KL}-\mathrm{TLP} ; \mathrm{WHC}=\mathrm{AT}$

$\mathrm{KAT}=\mathrm{TLP}+\mathrm{KSA}$

dimana KSA = ketersediaan air tanah aktual, $\mathrm{WHC}=$ kapasitas simpan air tanah, dan $k=$ tetapan yang nilainya dihitung dengan persamaan:

$$
k=p o+p i / \mathrm{WHC}
$$

dimana po $=1,000412351$ dan $\mathrm{p} 1=-1,073807306$. Nilai k yang diperoleh untuk lokasi penelitian sebesar 0,992742

j. Mengisi kolom perubahan kandungan air tanah (dKAT), dimana dKAT suatu bulan adalah KAT bulan tersebut dikurangi KAT bulan sebelumnya:

$$
\mathrm{dKATi}=\mathrm{KATi}-\mathrm{KATi}-1
$$

k. Mengisi kolom evapotranspirasi aktual, ETa:

Jika $\mathrm{CH} \geq \mathrm{ETp} \rightarrow \mathrm{ETa}=\mathrm{ETp}$

$\mathrm{CH}<\mathrm{ETp} \rightarrow \mathrm{ETa}=\mathrm{CH}+\mathrm{IdKATI}$

Jika hasil perhitungannya ETa $>$ ETp maka digunakan nilai $\mathrm{ETa}=\mathrm{ETp}$ (nilai $\mathrm{ETa}$ maksimum $=\mathrm{ETp}$; nilai ETa tidak bisa melampaui nilai ETp)

1. Mengisi kolom defisit, $\mathrm{D}=\mathrm{ETp}-\mathrm{Eta}$

m. Mengisi kolom surplus, $\mathrm{S}=\mathrm{CH}-\mathrm{ETp}-\mathrm{dKAT}$

\section{HASIL DAN PEMBAHASAN}

\section{Keadaan Umum Lokasi Penelitian}

Secara administratif pemerintahan, Pulau Ambon dengan luas $761 \mathrm{~km}^{2}$ terdiri dari dua wilayah kabupaten/kota, yaitu Kota Ambon yang terletak di bagian selatan-tengah Pulau Ambon dan sebagiannya yang terletak di bagian utara, ujung barat dan ujung timur Pulau Ambon masuk dalam wilayah Kabupaten Maluku Tengah. Secara astronomis Pulau Ambon berada pada 03-04 ${ }^{\circ}$ Lintang Selatan dan $127-129^{\circ}$ Bujur Timur, dan secara geografis mempunyai batas-batas alam sebagai berikut (BPS, 2018): sebelah utara berbatasan dengan wilayah Kabupaten Seram Bagian Barat; sebelah selatan 
dan barat berbatasan dengan Laut Banda; dan sebelah timur berbatasan dengan wilayah Kecamatan Pulau Haruku Kabupaten Maluku Tengah.

Pola iklim di lokasi penelitian adalah pola hujan lokal unimodal, dimana musim hujan berlangsung dari bulan Mei sampai Agustus sedangkan musim kering berlangsung dari bulan November sampai Februari. Bulan Maret-April dan September-Oktober merupakan periode peralihan/transisi (pancaroba) antara kedua musim tersebut; yaitu bulan Maret-April merupakan periode peralihan dari musim kering ke musim hujan dan bulan September-Oktober merupakan periode peralihan dari musim hujan ke musim kering (Laimeheriwa, 2014a).

Berdasarkan sifat morfologi, fisik dan kimia, di Pulau Ambon ditemukan lima jenis tanah, yaitu Podsolik, Aluvial, Kambisol, Litosol dan Gleisol. Penetapan jenis tanah mengacu pada Sistem Klasifikasi Tanah Nasional (PPT, 1983) dan Taksonomi Tanah (USDA, 1999) pada Kategori Great Group. Kelima jenis tanah ini memiliki tekstur mulai dari pasir berlempung hingga liat berdebu (Tim Amdal Unpatti, 2017).

Komoditi pertanian yang umumnya diusahakan oleh masyarakat petani dan/atau pengguna lahan pertanian lainnya terdiri dari tanaman pangan (ubi kayu, jagung, ubi jalar dan kacang tanah), aneka sayuran dan buahan serta tanaman perkebunan cengkeh, pala, kelapa, dan coklat. Luas panen masing-masing komoditi tersebut seperti yang disajikan pada Tabel 1 .

\section{Distribusi Tahunan dan Kondisi Ekstrem Curah Hujan}

\section{Distribusi curah hujan tahunan}

Hasil analisis data time series curah hujan selama 60 tahun pengamatan (periode 1959 - 2018) menunjukkan bahwa curah hujan $(\mathrm{CH})$ tahunan di Pulau Ambon berkisar antara yang paling rendah $1.506 \mathrm{~mm}$ hingga tertinggi $5.710 \mathrm{~mm}$ dengan nilai rata-rata 3.055 mm (Gambar 1). Dalam kurun waktu 60 tahun telah terjadi penyimpangan curah hujan kurang dari kondisi normal (curah hujan $<0,85$ dari curah hujan normal atau rata-rata) sebanyak 23 kali atau sekitar 38,3\% dari 60 tahun kejadian hujan.

\section{Curah hujan ekstrem El Nino}

Berdasarkan nilai ONI yang bersumber dari pengukuran suhu muka laut (Sea Surface Temperature) oleh NOAA pada region Nino 3.4 di Samudera Pasifik diperoleh gambaran bahwa sejak tahun 1959 hingga 2018 kejadian El-Nino di Indonesia berlangsung sebanyak 20 kali dengan frekuensi 1-5 tahun sekali atau rata-rata 3 tahun sekali.

Tabel 1. Luas panen komoditi pertanian di Pulau Ambon

\begin{tabular}{llcc}
\hline No. & Komoditi & Luas Panen (ha) & \% \\
\hline 1. & Tanaman Pangan: Ubi kayu, Jagung, Ubi Jalar & 449 & 2,8 \\
2. & Tanaman Sayuran & 864 & 5,5 \\
3. & Tanaman Buahan & 773 & 4,9 \\
4. & Tanaman Perkebunan: Cengkeh, Pala, Kelapa, Coklat & 13.736 & 86,8 \\
\hline & Jumlah & $\mathbf{1 5 . 8 2 2}$ & $\mathbf{1 0 0}$ \\
\hline
\end{tabular}

Sumber: dimodifikasi dari data BPS (2018)

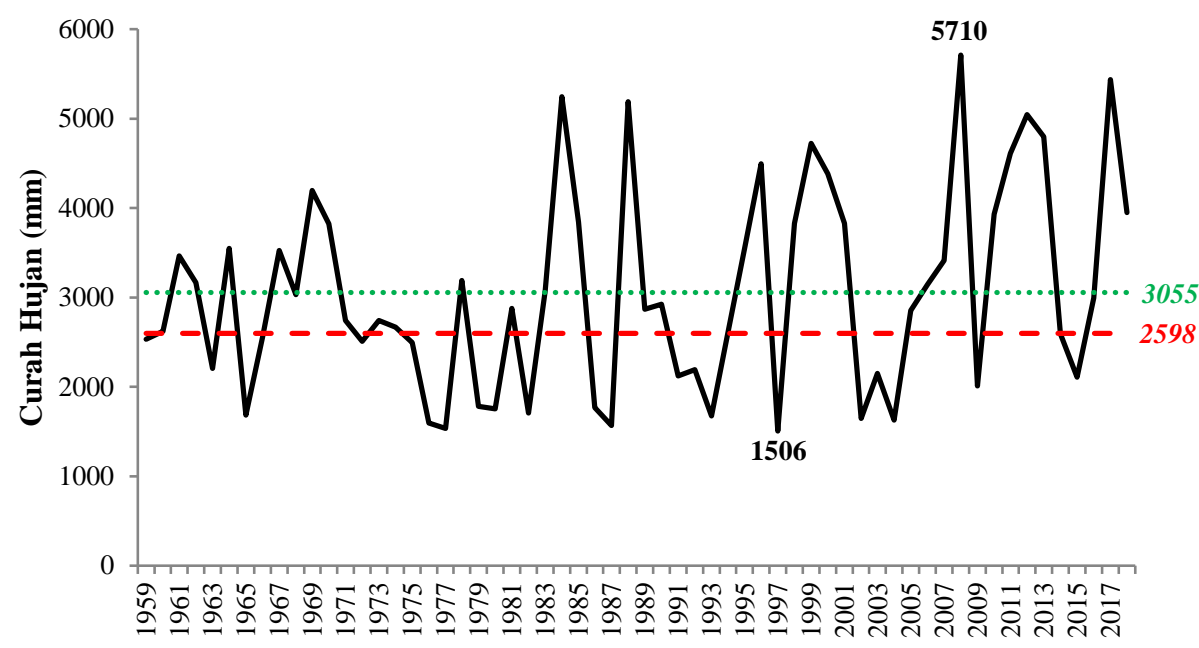

- Series CH Tahunan $\quad \cdots . . . .$. CH Normal (Rataan) $\quad$ - - - CH Dibawah Normal

Gambar 1. Distribusi curah hujan tahunan di Pulau Ambon 
Tabel 2. Curah hujan selama tiga tahun kejadian El-Nino paling ekstrem di Pulau Ambon selama 60 tahun periode 1959 $-2018$

\begin{tabular}{|c|c|c|c|c|c|c|c|c|c|c|c|c|c|}
\hline \multirow{2}{*}{ Tahun } & \multicolumn{13}{|c|}{ Curah Hujan (mm) } \\
\hline & Jan & Feb & Mar & Apr & Mei & Jun & Jul & Ags & Sep & Okt & Nov & Des & Setahun \\
\hline 1977 & 9 & 23 & 10 & 186 & 115 & 643 & 159 & 248 & 67 & 0 & 0 & 74 & 1534 \\
\hline 1987 & 230 & 165 & 193 & 88 & 337 & 51 & 11 & 78 & 67 & 81 & 41 & 224 & 1566 \\
\hline 1997 & 78 & 218 & 155 & 169 & 100 & 161 & 475 & 3 & 1 & 7 & 23 & 117 & 1506 \\
\hline $\begin{array}{l}\text { Rata-rata } \\
\text { El Nino }\end{array}$ & 106 & 135 & 119 & 148 & 184 & 285 & 215 & 110 & 45 & 29 & 21 & 138 & 1535 \\
\hline $\begin{array}{c}\text { Normal } \\
\text { (Rata-rata) }\end{array}$ & 137 & 120 & 148 & 189 & 429 & 597 & 526 & 347 & 231 & 132 & 75 & 124 & 3055 \\
\hline \multicolumn{14}{|c|}{ Penyimpangan dari kondisi normal } \\
\hline $\mathrm{mm}$ & -31 & 15 & -29 & -41 & -245 & -312 & -311 & -237 & -186 & -103 & -54 & 14 & -1520 \\
\hline$\%$ & -23 & 13 & -20 & -22 & -57 & -52 & -59 & -68 & -81 & -78 & -72 & 11 & -50 \\
\hline
\end{tabular}

Tabel 3. Perhitungan neraca air lahan pada kondisi curah hujan rata-rata

\begin{tabular}{|c|c|c|c|c|c|c|c|c|c|c|}
\hline Bulan & $\mathrm{CH}$ & $\mathrm{T}$ & ETp & CH-ETp & APWL & KAT & dKAT & ETa & $\mathrm{D}$ & $\mathrm{S}$ \\
\hline Januari & 137 & 27,4 & 143 & -6 & -99 & 235 & -3 & 140 & 3 & 0 \\
\hline Februari & 120 & 27,3 & 142 & -22 & -121 & 223 & -12 & 132 & 10 & 0 \\
\hline Maret & 148 & 27,3 & 142 & 6 & & 229 & 6 & 142 & 0 & 0 \\
\hline April & 189 & 26,8 & 138 & 51 & & 280 & 51 & 138 & 0 & 0 \\
\hline Mei & 429 & 26,4 & 135 & 294 & & 310 & 30 & 135 & 0 & 264 \\
\hline Jun & 597 & 25,6 & 128 & 469 & & 310 & 0 & 128 & 0 & 469 \\
\hline Juli & 526 & 25,2 & 125 & 401 & & 310 & 0 & 125 & 0 & 401 \\
\hline Agustus & 347 & 25,1 & 124 & 223 & & 310 & 0 & 124 & 0 & 223 \\
\hline September & 231 & 25,7 & 129 & 102 & & 310 & 0 & 129 & 0 & 102 \\
\hline Oktober & 132 & 26,6 & 137 & -5 & -5 & 305 & -5 & 137 & 0 & 0 \\
\hline November & 75 & 27,5 & 144 & -69 & -74 & 250 & -55 & 130 & 14 & 0 \\
\hline Desember & 124 & 27,4 & 143 & -19 & -93 & 238 & -12 & 136 & 7 & 0 \\
\hline Setahun & 3055 & & 1630 & & & & 0 & 1596 & 34 & 1459 \\
\hline
\end{tabular}

Keterangan: Kedalaman tinjau: $1 \mathrm{~m}$; Tekstur tanah: Kapasitas lapang: $310 \mathrm{~mm}$; Titik layu permanen: $140 \mathrm{~mm}$; water holding capacity: $170 \mathrm{~mm} ; \mathrm{CH}=$ curah hujan $(\mathrm{mm}) ; \mathrm{T}=$ suhu udara $\left({ }^{\circ} \mathrm{C}\right) ; \mathrm{ETp}=$ evapotranspirasi potensial $(\mathrm{mm}) ; \mathrm{APWL}=$ akumulasi air yang hilang secara potensial $(\mathrm{mm})$; KAT = kandungan air tanah $(\mathrm{mm})$; dKAT $=$ perubahan kandungan air tanah $(\mathrm{mm}) ; \mathrm{ETa}=$ evapotranspirasi aktual $(\mathrm{mm}) ; \mathrm{D}=$ defisit air $(\mathrm{mm}) ; \mathrm{S}=\operatorname{surplus}$ air $(\mathrm{mm})$.

Tabel 4. Perhitungan neraca air lahan pada kondisi curah hujan ekstrem kering (El-Nino)

\begin{tabular}{|c|c|c|c|c|c|c|c|c|c|c|}
\hline Bulan & $\mathrm{CH}$ & $\mathrm{T}$ & ETp & CH-ETp & APWL & KAT & dKAT & ETa & $\mathrm{D}$ & $\mathrm{S}$ \\
\hline Januari & 106 & 27,4 & 143 & -37 & -371 & 159 & -5 & 111 & 32 & 0 \\
\hline Februari & 135 & 27,3 & 142 & -7 & -378 & 158 & -1 & 136 & 6 & 0 \\
\hline Maret & 119 & 27,3 & 142 & -23 & -401 & 156 & -2 & 121 & 21 & 0 \\
\hline April & 148 & 26,8 & 138 & 10 & & 166 & 10 & 138 & 0 & 0 \\
\hline Mei & 184 & 26,4 & 135 & 49 & & 215 & 49 & 135 & 0 & 0 \\
\hline Jun & 285 & 25,6 & 128 & 157 & & 310 & 95 & 128 & 0 & 62 \\
\hline Juli & 215 & 25,2 & 125 & 90 & & 310 & 0 & 125 & 0 & 90 \\
\hline Agustus & 110 & 25,1 & 124 & -14 & -14 & 296 & -14 & 124 & 0 & 0 \\
\hline September & 45 & 25,7 & 129 & -84 & -98 & 235 & -61 & 106 & 23 & 0 \\
\hline Oktober & 29 & 26,6 & 137 & -108 & -206 & 190 & -45 & 74 & 63 & 0 \\
\hline November & 21 & 27,5 & 144 & -123 & -329 & 164 & -26 & 47 & 97 & 0 \\
\hline Desember & 138 & 27,4 & 143 & -5 & -334 & 164 & 0 & 138 & 5 & 0 \\
\hline Setahun & 1535 & & 1630 & -95 & & & 0 & 1383 & 247 & 152 \\
\hline
\end{tabular}

Sementara itu, berdasarkan data time series curah hujan 60 tahun periode 1959-2018 di Pulau Ambon (Gambar 1), dari 23 kali kejadian penyimpangan curah hujan yang kurang dari kondisi normalnya, 16 kali diantaranya bertepatan dengan kejadian El-Nino di wilayah Indonesia yang tercatat pada region Nino 3.4, yaitu pada tahun: 1963, 1965, 1972, 1976, 1977, 1979, 1982, 1986, 1987, 1991, 1997, 2002, 2004, 2009, 2014, dan 2015; frekuensi 1-7 tahun sekali atau rata-rata 4 tahun sekali. 
Kejadian curah hujan di bawah normal (kekeringan) dan fenomena El Nino tersebut memberikan gambaran bahwa kejadian kekeringan di Pulau Ambon tidak selalu bersamaan dengan kejadian El Nino, dan kejadian El Nino tidak selalu menyebabkan kekeringan atau curah hujan di bawah normal. Pada tahun 1959, 1966, 1975, 1980, 1992, 1993, dan 2003 jumlah curah hujan di Pulau Ambon berada pada kondisi dibawah normal ( $<2598 \mathrm{~mm} /$ tahun) tetapi tahun-tahun tersebut tidak tercatat sebagai tahun-tahun El Nino. Selanjutnya, tahun 1968, 1969, 1994, dan 2006 tercatat sebagai tahun-tahun El Nino tetapi tidak menyebabkan kekeringan atau curah hujan di Pulau Ambon dibawah kondisi normalnya.

Ketika intensitas El Nino kuat hingga sangat kuat dengan nilai ONI > 1,5 maka fenomena ini akan tetap berlangsung di wilayah Pulau Ambon. Selama periode 60 tahun terakhir kejadian ini berlangsung selama 7 kali, yaitu pada tahun 1965, 1972, 1982, 1987, 1991, 1997, dan 2015. Frekuensi kejadian El Nino dengan intensitas kuat ini adalah 4-10 tahun sekali atau rata-rata 7 tahun sekali. Namun ketika intensitas El Nino lemah hingga sedang dengan nilai ONI 0,5 sampai dengan 1.5, dari 13 tahun kejadian El Nino dengan intensitas tersebut, hanya sembilan kali kejadian ini terjadi di wilayah Pulau Ambon, yaitu pada tahun 1963, 1976, 1977, 1979, 1986, 2002, 2004, 2009 dan 2014.

Tiga tahun kejadian El-Nino yang paling ekstrem (curah hujan tahunan terendah) di Pulau Ambon berlangsung pada tahun 1977, 1987 dan 1997 (Tabel 2) dengan jumlah curah hujan tahunan masing-masing sebesar $1.534 \mathrm{~mm}, 1.566$ dan $1.506 \mathrm{~mm}$ atau berkurang sebesar 48,7-50,7\% dari kondisi normalnya.

Terlihat dalam Tabel 2, pada kondisi ekstrem ElNino penurunan curah hujan dari kondisi normalnya selama setahun sebesar $1.520 \mathrm{~mm}$ atau $50 \%$ dari kondisi normalnya. Penurunan curah hujan akibat El Nino yang biasanya dimulai sejak bulan April hingga November berlangsung tiap bulannya sebesar 41-311 mm per bulan atau $22-81 \%$ dari kondisi normalnya; terbanyak dimulai pada bulan April, Mei, Juni dan September, Oktober, November. Presentase penurunan terbesar berlangsung dalam bulan Agustus hingga November dengan kisaran 68-81\%. Ini sesuai dengan Hidayat dan Ando (2014) yang menyimpulkan bahwa dampak El Nino terhadap penurunan curah hujan di sebagian besar wilayah Indonesia terlihat dominan pada periode Juni sampai dengan November, sementara pada periode Desember sampai dengan Mei relatif tidak memberikan pengaruh yang berarti terhadap penurunan curah hujan.

Bulan September, Oktober, dan November merupakan bulan-bulan dengan resiko kekeringan yang paling besar ketika El Nino berlangsung; dimana presentase penurunan dari kondisi normalnya $72-81 \%$ dengan curah hujan bulanan $\leq 45 \mathrm{~mm}$. Curah hujan yang kurang dari $45 \mathrm{~mm}$ per bulan akan menimbulkan cekaman air bagi tanaman yang sumber airnya hanya dari hujan. Banyak literatur dan pendapat ahli diantaranya oleh Schmidt-Ferguson (1951) dan Oldeman (1975) menyatakan bahwa curah hujan yang ideal untuk tanaman umur panjang minimal $60 \mathrm{~mm}$ per bulan, sedangkan untuk tanaman semusim atau umur pendek minimal $100 \mathrm{~mm}$ per bulan.

\section{Neraca Air Lahan}

Hasil perhitungan neraca air lahan di Pulau Ambon pada dua kondisi curah hujan seperti yang disajikan pada Tabel 3 dan 4.

Tabel 3 menunjukkan bahwa pada kondisi curah hujan normal defisit air yang terjadi di Pulau Ambon berlangsung selama 4 bulan (Oktober sampai dengan Februari) dengan kisaran defisit antara 3-14 mm/bulan dan total defisit $34 \mathrm{~mm} /$ tahun. Defisit air yang terjadi karena nilai potensial evapotrasnpirasi melebihi nilai aktualnya akibat curah hujan yang rendah. Sedangkan periode surplus air berlangsung selama 5 bulan, yaitu Mei sampai September dengan kisaran 102-469 mm dengan total surplus $1459 \mathrm{~mm} /$ tahun. Surplus air yang terjadi selama musim hujan sangat bergantung pada selisih antara curah hujan dan evapotranspirasi potensial dan perubahan kadar air tanah tiap bulannya. Secara grafis periode defisit dan surplus air tanah di Pulau Ambon pada kondisi curah hujan normal seperti yang disajikan pada Gambar 2.

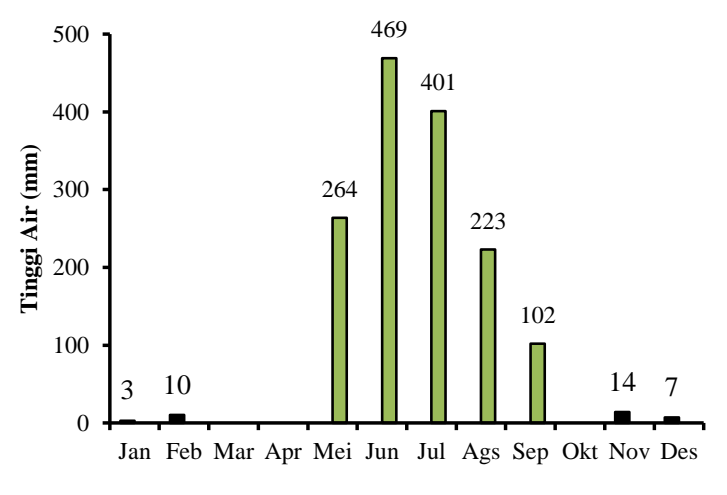

Defisit air : Nov s.d Feb $\square$ Surplus air : Mei s.d Sep

Gambar 2.Periode defisit dan surplus air di Pulau Ambon pada kondisi curah hujan normal (rata-rata)

Hasil perhitungan neraca air lahan Pulau Ambon pada kondisi curah hujan ekstrem El-Nino (Tabel 4) menunjukkan bahwa defisit air berlangsung selama 7 bulan, dimulai akhir musim hujan (September) hingga akhir musim kering (Maret) dengan kisaran defisit antara 5-97 mm/bulan dan total defisit $247 \mathrm{~mm} /$ tahun. Nampak bahwa selama periode musim kering di Pulau Ambon ketika fenomena El Nino terjadi defisit air terjadi setiap bulannya. Periode surplus air berlangsung hanya dalam 2 bulan, yaitu pada saat puncak curah hujan di bulan Juni dan Juli masing-masing sebesar 62 dan $90 \mathrm{~mm}$, dengan total surplus tahunan sebesar $152 \mathrm{~mm}$. Nampak bahwa kejadian El Nino akan berdampak pada berkurangnya ketersediaan air tanah terutama selama periode musim 
kemarau, yaitu Oktober-Maret dan pada awal musim hujan (April). Secara grafis, Gambar 3 memperlihatkan periode defisit dan surplus air tanah di Pulau Ambon pada kondisi El Nino.

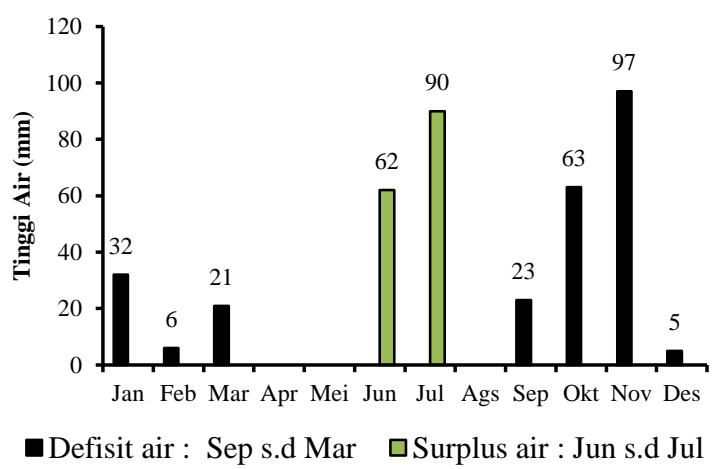

Gambar 3.Periode defisit dan surplus airdi Pulau Ambon pada saat El-Nino

Ketika El Nino terjadi, defisit air tahunan akan meningkat nilainya sebesar $626 \%$ dari kondisi normal atau meningkat sebesar $213 \mathrm{~mm}$, yaitu dari $34 \mathrm{~mm}$ menjadi $247 \mathrm{~mm}$ per tahun. Sementara itu, surplus air tahunan akan berkurang nilainya sebesar $90 \%$ dari kondisi normalnya atau $1307 \mathrm{~mm}$, yaitu dari $1459 \mathrm{~mm}$ menjadi $152 \mathrm{~mm}$.

Perubahan status neraca air lahan tersebut berdampak terhadap musim tanam atau periode tumbuh tersedia di Pulau Ambon. Terdapat berbagai metode dalam penentuan periode tumbuh di suatu wilayah; salah satunya berdasarkan nilai kandungan air tanah yang berada pada kondisi optimumnya. Kadar air tanah pada kondisi optimum (KATopt) dapat dihitung menggunakan persamaan (Las, 1992): KATopt $=\mathrm{KAT} \geq \mathrm{TLP}+0,5 \mathrm{x}$ WHC. Berdasarkan persamaan tersebut nilai KATopt yang diperoleh untuk lokasi penelitian adalah $\geq 225$ $\mathrm{mm} / \mathrm{m}$ kedalaman tanah. Kadar air tanah di Pulau Ambon pada kondisi curah hujan normal dan pada saat kejadian El Nino, seperti yang disajikan pada Gambar 4.

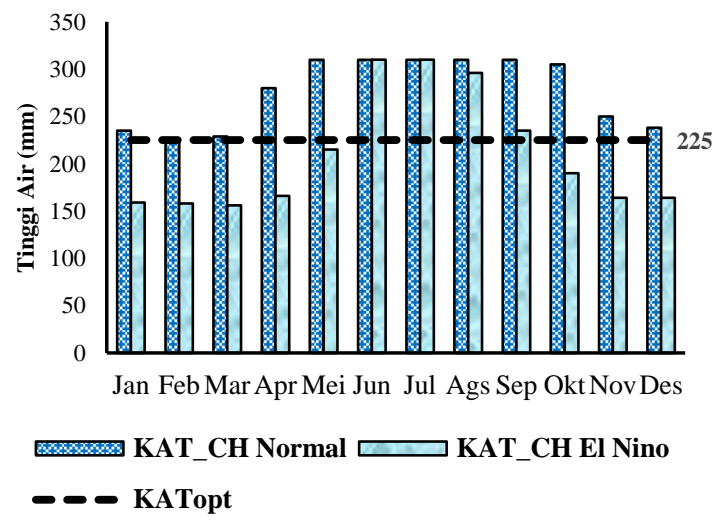

Gambar 4. Kadar air tanah (KAT) pada kondisi curah hujan normal dan El Nino di Pulau Ambon

Pada kondisi curah hujan normal air tanah pada kondisi optimum bagi tanaman berlangsung selama 11 bulan (Maret sampai dengan Januari) sedangkan pada bulan Februari kadar air tanah sedikit dibawah nilai optimumnya. Kondisi ini memberi gambaran bahwa pada kondisi curah hujan normal periode tumbuh di Pulau Ambon dapat berlangsung sepanjang tahun (12 bulan). Ketika fenomena El Nino, kadar air tanah pada kondisi optimum hanya berlangsung selama 4 bulan, yaitu Juni sampai dengan September. Sebulan sebelum dan sesudah periode KATopt, yaitu bulan Mei dan Oktober, kadar air tanah masing-masing sebesar $215 \mathrm{~mm}$ dan $190 \mathrm{~mm}$. Nilai kadar air tanah kedua bulan tersebut lebih mendekati nilai optimumnya $(225 \mathrm{~mm})$ dibandingkan nilai titik layu permanen $(140 \mathrm{~mm})$ sehingga dapat dipertimbangkan sebagai atau termasuk dalam periode tumbuh tersedia. Dengan demikian potensi masa tanam atau periode tumbuh tersedia di Pulau Ambon ketika fenomena El Nino berlangsung adalah selama 6 bulan (Mei sampai dengan Oktober) atau lebih pendek 6 bulan dibandingkan kondisi curah hujan normal.

\section{KESIMPULAN}

1. Fenomena El Nino di Pulau Ambon umumnya mulai berlangsung sejak bulan April hingga November; terbanyak dimulai pada bulan April, Mei, Juni dan September, Oktober, November. Selama periode 60 tahun (1959-2018), kejadian El Nino berlangsung sebanyak 16 kali dengan frekuensi 1-7 tahun sekali atau rata-rata 4 tahun sekali.

2. Kejadian El Nino yang paling ekstrim (curah hujan terendah) terjadi pada tahun 1977, 1987 dan 1997 dengan jumlah curah hujan tahunan masing-masing sebesar $1.534 \mathrm{~mm}, 1.566 \mathrm{~mm}$, dan $1.506 \mathrm{~mm}$ atau berkurang sebesar 48,7-50,7\% dari kondisi normalnya.

3. Ketika intensitas El Nino kuat hingga sangat kuat dengan nilai ONI > 1,5 maka fenomena ini akan tetap berlangsung di wilayah Pulau Ambon, yaitu selama 7 (tujuh) tahun: 1965, 1972, 1982, 1987, 1991, 1997, dan 2015. Frekuensi kejadian El Nino dengan intensitas kuat ini adalah 4-10 tahun sekali atau rata-rata 7 tahun sekali.

4. Ketika intensitas El Nino lemah hingga sedang dengan nilai ONI 0,5 sampai dengan 1.5, dari 13 tahun kejadian El Nino dengan intensitas tersebut, hanya 9 kali kejadian ini terjadi di wilayah Pulau Ambon, yaitu pada tahun 1963, 1976, 1977, 1979, 1986, 2002, 2004, 2009, dan 2014.

5. Berdasarkan perhitungan neraca air lahan, pada kondisi curah hujan ekstrem kering (El-Nino) terjadi defisit air selama 7 bulan, dimulai akhir musim hujan (September) hingga akhir musim kering (Maret) dengan kisaran defisit antara 5-97 $\mathrm{mm} /$ bulan dengan total defisit $247 \mathrm{~mm} /$ tahun atau nilainya bertambah sebesar $626 \%$ dari kondisi normal atau meningkat sebesar $213 \mathrm{~mm}$, yaitu dari $34 \mathrm{~mm}$ menjadi $247 \mathrm{~mm}$ per tahun. Sebaliknya, surplus air tahunan akan berkurang nilainya sebesar 
90\% atau $1307 \mathrm{~mm}$ dari kondisi normalnya, yaitu dari $1459 \mathrm{~mm}$ menjadi $152 \mathrm{~mm}$.

6. Kadar air tanah pada kondisi optimum bagi tanaman ketika kejadian El Nino hanya berlangsung selama 4 bulan (Juni sampai dengan September); lebih pendek 7 bulan dibandingkan kondisi normalnya, yaitu 11 bulan (Maret sampai dengan Januari).

\section{DAFTAR PUSTAKA}

Boer, R., J.S. Baharsjah, I. Las, dan H. Pawitan. 2003. Analisis Kerentanan dan Adaptasi Terhadap Keragaman dan Perubahan Iklim. Simposium Meteorologi Pertanian VI. 9-10 September 2003, Bogor, Indonesia. pp. 36-49.

BPS Badan Pusat Statistik. 2018. Kabupaten Maluku Tengah Dalam Angka. BPS Kabupaten Maluku Tengah, Masohi. 406p.

BPS Badan Pusat Statistik. 2018. Kota Ambon Dalam Angka. BPS Kota Ambon, Ambon. 381p.

IPCC Inter-Governmental Panel on Climate Change. 2001. A Special Repport Of Working Group III of the IPCC. Inter-Governmental Panel on Climate Change. Cambridge University Press.

Hidayat, R. dan K. Ando. 2014. Variabilitas curah hujan Indonesia dan hubungannya dengan ENSO/IOD: Estimasi menggunakan data JRA-25/JCDAS. Jurnal Agromet Indonesia 28: 1-8. DOI: 10.29244/j.agromet.28.1.1-8

Irwandi, H., M.I. Nasution, E. Kurniawan, dan Y. Megalina. 2017. Pengaruh El Nino terhadap variabilitas curah hujan di Sumatera Utara. FISITEK, Jurnal Ilmu Fisika dan Teknologi 1: 715.

Kaimuddin. 2000. Dampak Perubahan Iklim dan Tataguna Lahan Terhadap Keseimbangan Air Wilayah Sulawesi Selatan: Studi kasus DAS Walanae Hulu dan DAS Saddang. Disertasi. Program Pasca Sarjana, Institut Pertanian Bogor. Bogor.

Laimeheriwa, S. 2014a. Analisis peluang kejadian deret hari kering selama musim tanam di Kota Ambon. Jurnal Agrologia 3: 83-90.

Laimeheriwa, S. 2014b. Analisis tren perubahan curah hujan pada tiga wilayah dengan pola hujan yang berbeda di Provinsi Maluku. Jurnal Budidaya Pertanian 10: 71-78.

Laimeheriwa, S. 2015. Analisis Data Iklim Dalam Bidang Pertanian: Peluang Curah Hujan, Masa Tanam, Neraca Air Lahan Dan Klasifikasi Iklim Wilayah. Bahan Ajar Agroklimatologi. Fakultas Pertanian Unpatti. Ambon. 52p.

Las, I. 1992. Pewilayahan Komoditi Pertanian Berdasarkan Model Iklim Di Kabupaten Sikka dan Ende NTT. Disertasi. Bogor: Sekolah Pasca Sarjana, Institut Pertanian Bogor.

Nabilah, F., Y. Prasetyo, dan A. Sukmono. 2017. Analisis pengaruh fenomena El Nino dan La Nina terhadap curah hujan tahun 1998-2016 menggunakan indikator ONI (Oceanic Nino Index), Studi: Provinsi Jawa Barat. Jurnal Geodesi Undip 6: 402-412.

Nangimah, S.L., S. Laimeheriwa, dan M. Amba. 2018. Dampak fenomena El Nino dan La Nina terhadap keseimbangan air lahan pertanian dan periode tumbuh tersedia di Daerah Waeapo Pulau Buru. Jurnal Budidaya Pertanian 14(2): 66-74. DOI: 10.30598/jbdp.2018.14.2.66

NOAA National Oceanic and Atmospheric Administration_USA. 2019. Oceanic Nino Index (ONI): ENSO History Zone NINO 3.4. http://www.cpc.noaa.gov/products/analysis_mon itoring/. Diakses: 08 Februari 2019.

Oldeman, L.R. 1975. An Agroclimatic Map of Java. Contr. Centr. Res. Inst. Agric., 17, Bogor. 22p+map.

Osok, R.M., P.J. Kunu, dan S. Laimeheriwa. 2017. Kajian Dampak Perubahan Iklim Terhadap Ketersediaan Air Di Pulau Wamar Kabupaten Kepulauan Aru. Laporan Penelitian, Kerjasama dengan USAID` Jakarta. 53p.

Osok, R.M., A. Kastanya, F. Puturuhu, S. Laimeheriwa, dan R. Salman. 2019. Penyusunan Rencana Aksi Daerah Mitigasi dan Adaptasi Perubahan Iklim (RAD MAPI) Kota Ambon. Laporan Penelitian, Kerjasama dengan Bappeda dan Litbang Kota Ambon. 116p.

Schmidt, F.H. and H.A. Ferguson. 1951. Rainfall Types Based On Wet And Dry Period Ratios For Indonesia With Western New Guinea. Kementerian DMG-Perhubungan, Jakarta. 42p.

Sitaniapessy, P.M. 2002. Problema lingkungan pulau kecil di Maluku. Jurnal Pertanian Kepulauan 1: 79-82.

Tim Amdal Unpatti. 2017. Studi Amdal Pembangunan RSUP Kota Ambon. Dinas Kesehatan Provinsi Maluku, Ambon. 218p.

Thornthwaite, C.W. and J.P. Mather. 1957. Instruction And Tables For Computing Potensial Evapotranspiration And Te Water Balance. Drexel Institute of Climatology. New Jersey. 401p.

Utami, A.W., Jamhari, dan S. Hardyastuti. 2011. El Nino, La Nina dan penawaran pangan di Jawa, Indonesia. Jurnal Ekonomi Pembangunan 12: 257-271. DOI: 10.23917/jep.v12i2.197 